Original article

\title{
Depletion of the type 1 IGF receptor delays repair of radiation-induced DNA double strand breaks
}

\author{
Benjamin W. Turney ${ }^{\mathrm{a}, \mathrm{c}}$, Martin Kerr ${ }^{\mathrm{a}}$, Meenali M. Chitnis ${ }^{\mathrm{a}, \mathrm{b}}$, Kunal Lodhia ${ }^{\mathrm{a}}$, Yong Wang ${ }^{\mathrm{a}}$, \\ Johann Riedemann ${ }^{a}$, Mark Rochester ${ }^{a}$, Andrew S. Protheroe ${ }^{b}$, Simon F. Brewster ${ }^{c}$, \\ Valentine M. Macaulay ${ }^{\mathrm{a}, \mathrm{b}, *}$ \\ ${ }^{\mathrm{a}}$ Department of Oncology Laboratories, Weatherall Institute of Molecular Medicine; ${ }^{\mathrm{b}}$ Department of Oncology; and ${ }^{\mathrm{c}}$ Department of Urology, Cancer and Haematology Centre, \\ The Churchill Hospital, Oxford, UK
}

\section{A R T I C L E I N F O}

Article history:

Received 11 November 2011

Received in revised form 3 March 2012

Accepted 14 March 2012

Available online $\mathrm{xxxx}$

\section{Keywords:}

IGF

Type 1 IGF receptor

IGF-1R

Prostate cancer

DNA double strand break

DNA repair

\begin{abstract}
A B S T R A C T
Background and purpose: IGF-1R depletion sensitizes prostate cancer cells to ionizing radiation and DNAdamaging cytotoxic drugs. This study investigated the hypothesis that IGF-1R regulates DNA double strand break (DSB) repair.

Methods: We tested effects of IGF-1R siRNA transfection on the repair of radiation-induced DSBs by immunoblotting and immunofluorescence for $\gamma \mathrm{H} 2 \mathrm{AX}$, and pulsed-field gel electrophoresis. Homologous recombination (HR) was quantified by reporter assays, and cell cycle distribution by flow cytometry. Results: We confirmed that IGF-1R depletion sensitized DU145 and PC3 prostate cancer cells to ionizing radiation. DU145 control transfectants resolved radiation-induced DSBs within $24 \mathrm{~h}$, while IGF-1R depleted cells contained 30-40\% unrepaired breaks at $24 \mathrm{~h}$. IGF-1R depletion induced significant reduction in DSB repair by HR, although the magnitude of the repair defect suggests additional contributory factors. Radiation-induced G2-M arrest was attenuated by IGF-1R depletion, potentially suppressing cell cycle-dependent processes required for HR. In contrast, IGF-1R depletion induced only minor radiosensitization in LNCaP cells, and did not influence repair. Cell cycle profiles were similar to DU145, so were unlikely to account for differences in repair responses.

Conclusions: These data indicate a role for IGF-1R in DSB repair, at least in part via HR, and support use of IGF-1R inhibitors with DNA damaging cancer treatments.

(C) 2012 Elsevier Ireland Ltd. All rights reserved. Radiotherapy and Oncology xxx (2012) xxx-xxx
\end{abstract}

The type 1 insulin-like growth factor receptor (IGF-1R) has a well-recognized role in promoting proliferation and cell cycle progression, and in protecting from apoptosis $[1,2]$. We and others established that the IGF-1R is up-regulated in primary prostate cancer, and is detectable in prostate cancer bone metastases [37]. Our recent demonstration of high and/or increasing IGF-1R expression with clinical prostate cancer progression is consistent with experimental evidence that IGF-1R expression is androgenregulated in prostate cancer [8-10].

Targeting of the type 1 IGF receptor (IGF-1R) has been shown to enhance sensitivity to cytotoxic drugs and ionizing radiation, generally attributed to apoptosis induction [11-14]. In support of these data, IGF-1R inhibitory drugs enhance clinical effects of certain forms of chemotherapy, but negative Phase III results suggest

* Corresponding author. Address: Department of Oncology Laboratories, Weatherall Institute of Molecular Medicine, John Radcliffe Hospital, Oxford OX3 9DS, United Kingdom.

E-mail address: valentine.macaulay@oncology.ox.ac.uk (V.M. Macaulay). that we do not understand enough about the biology of the IGF-1R to use these new agents effectively [15].

The first data linking the IGF-1R to DNA repair came from a study of breast cancer: patients whose tumours over-expressed the IGF-1R were shown to be more likely to experience early recurrence within the irradiated site, indicating clinical radio-resistance [16]. Potential mechanisms connecting the IGF-1R to DNA repair include a link with the function of Ataxia Telangiectasia Mutated (ATM) that coordinates the response to DNA double strand breaks (DSBs; 17), and the reported interaction between the IGF-1R docking protein insulin-receptor substrate-1 (IRS-1) and RAD51, required for the strand invasion step of homologous recombination (HR) repair [18]. Additionally, an IGF-1R antibody was shown to inhibit the expression and activity of topoisomerase II, required for induction and repair of replication-associated DSBs [19].

We wished to investigate effects of IGF-1R targeting on the cellular response to DNA damage. Both IGF-1R antibodies and kinase inhibitors can affect the function of the closely-related insulin receptor, either directly or by down-regulating insulin receptors in IGF-1R:insulin receptor hybrids [20-22]. In order to study the

0167-8140/\$ - see front matter @ 2012 Elsevier Ireland Ltd. All rights reserved. http://dx.doi.org/10.1016/j.radonc.2012.03.009 
specific contribution of IGF-1R to the DNA damage response, we used gene silencing to deplete IGF-1R in human prostate cancer cells. Our previous investigation using this approach demonstrated that IGF-1R knockdown sensitized prostate cancer cells to agents that induce DNA DSBs, but not to chemotherapeutic agents that kill cells without damaging DNA [23]. These results suggested that the ability to regulate apoptosis may not be the only means by which IGFs influence radio- and chemo-sensitivity. The aim of the current study was to investigate whether IGF-1R depletion modifies the response to DNA DSBs induced by ionizing radiation. Our data suggest that IGF-1R depleted prostate cancer cells show a delay in DNA repair, and support a role for the IGF axis in DSB repair via HR.

\section{Materials and methods}

\section{Cell lines and siRNA transfection}

Human prostate cancer cell lines DU145, PC3 and LNCaP were obtained from Cancer Research UK Laboratories, Clare Hall Hertfordshire, UK. DU145 cells are androgen independent, PTEN wildtype, PC3 are androgen independent, PTEN null, and LNCaP are androgen sensitive, mutant PTEN, IRS-1 null cells [24-27]. DU145 and LNCaP cells were cultured in RPMI 1640 medium, and PC 3 cells in Hams F12 medium, each supplemented with 10\% faetal calf serum (FCS). Cell line identity was verified by short tandem repeat multiplex assay (AmpF $\ell S T R{ }^{\circledR}$ Identifier PCR Amplification Kit, Applied Biosystems), and all cell lines were negative for Mycoplasma when tested using the MycoAlert Mycoplasma Detection kit (Lonza Rockland Inc., Rockland, US). Cultures were transfected at 30-40\% confluence using Oligofectamine (Invitrogen) with non-silencing Allstars (Qiagen) or scrambled sequence control siRNA, or IGF-1R siRNA (Hs_IGF1R_1, Qiagen; or IGF-1R R4 siRNA) as described $[23,28]$. Cells were irradiated in a Caesium-137 source (GammaCell, Atomic Energy of Canada) at 3 Gy per minute.

\section{Western blotting and immunoprecipitation}

Forty-eight hours after siRNA transfection, cells were lysed in IGF-1R lysis buffer (50 mM HEPES pH 7.5, $100 \mathrm{mM} \mathrm{NaCl,} 10 \mathrm{mM}$ EDTA, $1 \%$ Triton X-100, $4 \mathrm{mM}$ sodium pyrophosphate, $2 \mathrm{mM}$ sodium orthovanadate, $10 \mathrm{mM}$ sodium fluoride, $1 \mathrm{mM}$ PMSF or $150 \mathrm{mM}$ Pefabloc (Roche), EDTA-free protease inhibitor cocktail, Roche) as described [17]. Lysates were analysed by SDS polyacrylamide gel electrophoresis and Western blotting, using primary antibodies to IGF-1R $\beta$ (\#3027, Cell Signaling Technology, CST), insulin receptor $\alpha$ (sc710, Santa Cruz), IRS-1 (\#2382, CST) and $\beta$ tubulin (Sigma-Aldrich). Some cultures underwent initial lysis in IGF-1R lysis buffer to generate a Triton-soluble fraction, and the Triton-insoluble pellet was lysed in IGF-1R lysis buffer in which the Triton X-100 was replaced by $1 \%$ SDS. The SDS soluble fraction was sonicated for $10 \mathrm{~s}$ on ice at $70 \%$ maximum output on a Sonoplus GM70 sonicator (Bandelin Electronic, Berlin) prior to analysis by Western blotting for $\gamma \mathrm{H} 2 \mathrm{AX}$ (\#2577, CST) and heterochromatin protein-1 (HP1 $\alpha$, loading control for SDS-soluble fraction; \#2616, CST). Scanned images were quantified using ImageJ software and protein levels were corrected for loading. For immunoprecipitation, DU145 cells were serum-starved overnight and treated with $50 \mathrm{nM}$ IGF-I (long-R3 IGF-I, Sigma) for $30 \mathrm{~min}$ prior to lysis in IGF-1R lysis buffer. Lysates were precleared using Protein $A$ and $\mathrm{G}$-Sepharose for $30 \mathrm{~min}$ at $4{ }^{\circ} \mathrm{C}$ on a rotating wheel. After centrifugation at $8000 \mathrm{~g}$ for $1 \mathrm{~min}$ at $4{ }^{\circ} \mathrm{C}$, precleared lysates were immunoprecipitated with IRS-1 antibody (as above) or rabbit IgGs (SigmaAldrich), overnight at $4{ }^{\circ} \mathrm{C}$. Bound antibody was collected with Protein $\mathrm{A}$ and $\mathrm{G}$-Sepharose for $90 \mathrm{~min}$ at $4{ }^{\circ} \mathrm{C}$, washed 3 times with IGF-1R lysis buffer, and analysed by SDS-PAGE and immunoblotting for IRS-1 and RAD51 (14B4, Abcam).

\section{Immunofluorescence}

DU145 cells were seeded onto coverslips and after $24 \mathrm{~h}$ were siRNA-transfected as above. After $48 \mathrm{~h}$, cells were irradiated ( $5 \mathrm{~Gy}$ ), and at intervals were fixed in fresh $4 \%$ paraformaldehyde, $250 \mathrm{mM}$ HEPES pH 7.4, 0.1\% Triton X-100 for $20 \mathrm{~min}$ at $4{ }^{\circ} \mathrm{C}$. After washing 3 times in ice-cold PBSA, cells were permeabilised in $0.5 \%$ TritonX-100 for 20 min on ice, washed and blocked with 5\% FCS in PBS at room temperature for $30 \mathrm{~min}$. Coverslips were incubated with $\gamma \mathrm{H} 2 \mathrm{AX}$ antibody (\#2577, CST) overnight at $4{ }^{\circ} \mathrm{C}$, washed, and bound antibody was detected with Alexa Fluor 488-conjugated anti-rabbit secondary antibody (Invitrogen) in $5 \%$ bovine serum albumin (BSA) in PBS for 30 min at room temperature. After washing, DNA was stained with $1 \mu \mathrm{M}$ TO-PRO-3 (Invitrogen) in PBS, and coverslips were mounted in Fluoromount. Slides were examined by confocal microscopy (Bio-Rad) and nuclear foci were counted in 20-30 cells per condition.

\section{Pulsed field gel electrophoresis (PFGE)}

Methods for PFGE were based on [29,30]. The CHEF (contourclamped homogeneous electric field) mammalian genomic DNA kit (Bio-Rad) was used to prepare agarose plugs containing $1 \times 10^{6}$ prostate cancer cells in $1 \%$ Clean-Cut agarose (Bio-Rad). Plugs were irradiated at $20 \mathrm{~Gy}$, incubated at $37^{\circ} \mathrm{C}$, and at intervals of 2-36 h were lysed in $100 \mathrm{mM}$ EDTA ( $\mathrm{pH} 8.0$ ), $0.2 \%$ sodium deoxycholate, $1 \%$ sodium lauryl sarcosine, $1 \mathrm{mg} / \mathrm{ml}$ proteinase $\mathrm{K}$ for $18 \mathrm{~h}$ at $50^{\circ} \mathrm{C}$. After washing four times in $20 \mathrm{mM}$ TrisCl pH 8.0, 50 mM EDTA at room temperature, the plugs were loaded onto $1 \%$ agarose gels (Ultrapure DNA grade agarose, BioRad) in parallel with yeast chromosome size markers. PFGE was performed in TBE as described [29] using a CHEF-DRII apparatus (Bio-Rad, Richmond, CA) with an electric field reorientation angle of $120^{\circ}$, field strength $6 \mathrm{~V} / \mathrm{cm}$, pulses ramped from 50 to $60 \mathrm{~s}$. After electrophoresis for $72 \mathrm{~h}$ at $4{ }^{\circ} \mathrm{C}$, gels were stained for $30 \mathrm{~min}$ in $0.5 \mathrm{mg} / \mathrm{ml}$ ethidium bromide, destained in distilled water and imaged using a Gel Doc 2000 fluoroimager (Bio-Rad).

\section{Assay for homologous recombination (HR)}

DU145 cells were transfected with HR reporter pDR-GFP, obtained from Professor Ian Hickson, Weatherall Institute of Molecular Medicine, Oxford, originally from Professor M. Jasin, Sloan-Kettering Cancer Center, New York [31]. Transfected clones were selected and expanded in $2 \mu \mathrm{g} / \mathrm{ml}$ puromycin. Genomic DNA was extracted using the Wizard Genomic DNA extraction kit (Promega) to screen for pDR-GFP integration. GFP-specific primers (forward: 5'-CCTTCGGGCATGGCGGACTTG-3'; reverse: 5'-AGGGCG TTCGGCTTCTGG- $3^{\prime}$ ) were used in a PCR with an initial cycle of $95{ }^{\circ} \mathrm{C}$ for $12 \mathrm{~min}, 35 \mathrm{cycles}$ of $94^{\circ} \mathrm{C}$ for $30 \mathrm{~s}, 60^{\circ} \mathrm{C}$ for $30 \mathrm{~s}, 72^{\circ} \mathrm{C}$ for $40 \mathrm{~s}$, and a final cycle of $72^{\circ} \mathrm{C}$ for $10 \mathrm{~min}$. Stable pDR-GFP transfectants were transiently transfected with control or IGF-1R siRNAs, and the following day with pCMV-Sce (provided by Professor Ian Hickson, WIMM Oxford) and pDsRed2-Mito (BD Clontech), using Genejuice transfection agent (Novagen). Two days later ( 3 days after siRNA transfection) cells were analysed by flow cytometry on a FACSCaliber flow cytometer (Becton Dickson Biosciences), analysing 50,000 cells for each condition using CellQuest software (Becton Dickinson Biosciences). GFP-positive cells were calculated as a percentage of the transfected (pDsRed2-Mito-positive) population. Parallel cultures seeded on coverslips were harvested for fluorescent microscopy by fixing on ice using $4 \%$ paraformaldehyde in $250 \mathrm{mM}$ HEPES $\mathrm{pH} 7.5,0.1 \%$ Triton for 20 min. Coverslips were washed 4 times with PBS, mounted with Antifade Gold mounting medium (Molecular Probes), visualised 

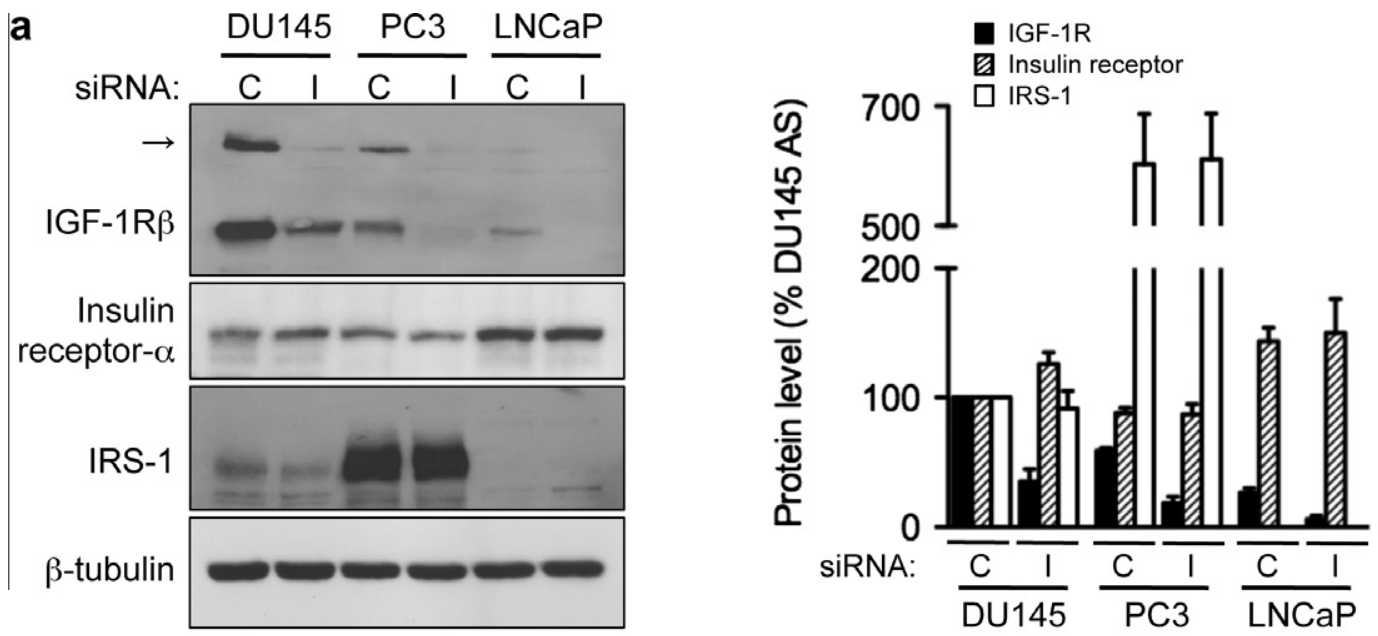

b DU145
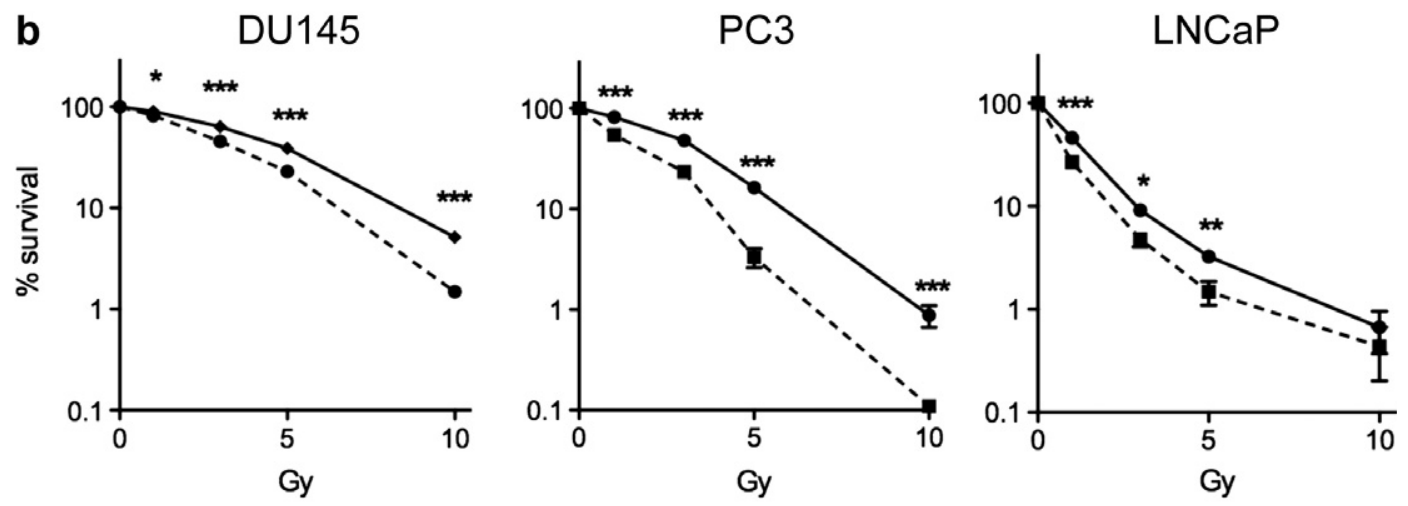

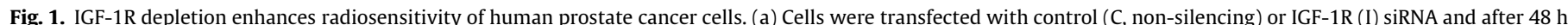

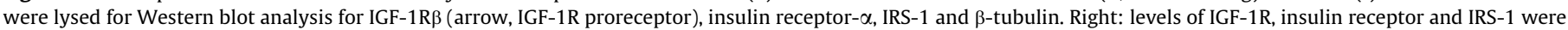

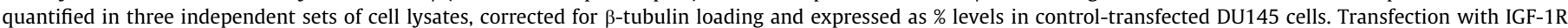

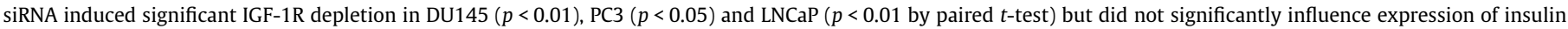

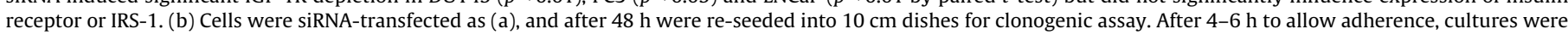

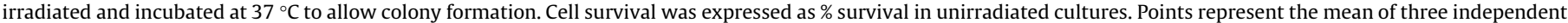

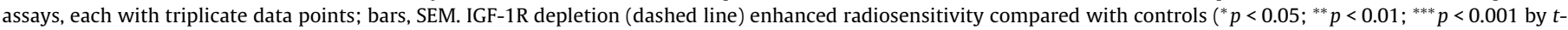
test).

Table 1

Effect of IGF-1R depletion on cell cycle distribution after irradiation.

\begin{tabular}{llclll}
\hline & \multicolumn{3}{l}{ SF1 $(\%)$} & & SF10 $(\%)$ \\
\cline { 2 - 3 } \cline { 5 - 6 } Cell line & Control siRNA & IGF-1R siRNA & & Control siRNA & IGF-1R siRNA \\
\hline DU145 & $90.0 \pm 2.4$ & $82 \pm 1.0^{*}$ & & $5.1 \pm 0.4$ & $1.5 \pm 0.2^{* * *}$ \\
PC3 & $82.1 \pm 4.0$ & $54.6 \pm 3.0^{* * *}$ & & $0.9 \pm 0.2$ & $0.1 \pm 0^{*}$ \\
LNCaP & $45.9 \pm 1.2$ & $26.7 \pm 2.5^{* * *}$ & & $0.7 \pm 0.3$ & $0.4 \pm 0.2$ \\
\hline
\end{tabular}

Data from assays shown in Fig. 1b are tabulated to show radiation survival, expressed as \% survival in unirradiated cells (mean \pm SEM of three independent assays) after $1 \mathrm{~Gy}$ (SF1) and $10 \mathrm{~Gy}$ (SF10) ionizing radiation. IGF-1R depleted DU145 and PC3 cells were significantly more radiosensitive than controls; LNCaP cells showed significant sensitization only at $1 \mathrm{~Gy}$.

$p<0.05 ;{ }^{* * *} p<0.001$ by $t$-test.

on an Axioskop 2 plus microscope (Zeiss), and images were captured using Axiovision 3.1.

\section{Cell cycle analysis}

Cells were transfected with siRNAs and after $48 \mathrm{~h}$ were irradiated (5 Gy). At intervals, cells were fixed with ice cold 70\% ethanol in PBS and stored at $-20^{\circ} \mathrm{C}$ for up to 2 weeks. After washing twice with PBS, cells were treated with $100 \mu \mathrm{g} / \mathrm{ml}$ RNase A and $50 \mu \mathrm{g} / \mathrm{ml}$ propidium iodide in PBS for $30 \mathrm{~min}$ at $37^{\circ} \mathrm{C}$. DNA content was quantified on a FACSCaliber flow cytometer with CellQuest software.

\section{Statistical analysis}

Data were analysed using GraphPad Prism version 5 (GraphPad software, San Diego, California, USA), performing $t$-tests for comparison of two groups of data, and one way analysis of variance (ANOVA) for multiple ( $\geqslant 3$ ) groups.

\section{Results and discussion}

We previously reported that IGF-1R depletion induces apoptosis and enhances the sensitivity of human prostate cancer cells to ionizing radiation and DNA damaging cytotoxic drugs [23]. The aim of the current study was to ask whether this effect is due, at least in part, to altered DSB repair. Initially we assessed IGF-1R expression in DU145, PC3 and LNCaP prostate cancer cells. Consistent with previous reports [23,27], PC3 and LNCaP cells expressed lower IGF-1R levels than DU145, and LNCaP cells lacked IRS-1 (Fig. 1a). We confirmed that transfection with IGF-1R siRNA induced depletion of IGF-1R, without influencing expression of insulin receptor or IRS-1 (Fig. 1a). In each subsequent experiment to analyse effects of this manipulation on radiosensitivity and DNA repair, IGF-1R depletion was confirmed by western blotting. Parallel cultures were used in clonogenic assays to assess cell survival after irradiation. Comparison of control-transfected cultures indicated that DU145 cells were relatively radioresistant, PC3 intermediate and LNCaP more radiosensitive. The same pattern of relative 
radiosensitivity of DU145 and LNCaP cells had been noted previously [32]. Following IGF-1R depletion, there was evidence of enhanced sensitivity to ionizing radiation in DU145 and PC3 cells. Similar IGF-1R down-regulation was achieved in LNCaP cells, and was associated with sensitization to $1 \mathrm{~Gy}$ ionizing radiation; although statistically significant, effects at 3 and 5 Gy were modest and unlikely to be biologically important (Fig. $1 \mathrm{~b}$ and Table 1 ). The results in all three cell lines were consistent with our previous report [23]. We did not check knockdown by fluorescence microscopy, although when we did this previously [33], we observed relatively uniform IGF-1R depletion in $\sim 80-90 \%$ of cells, with $\sim 10-20 \%$ retaining control IGF-1R levels. Therefore, it is possible that the results reported here could underestimate the true phenotype induced by IGF-1R depletion,

Ionizing radiation induces a variety of DNA lesions including single-strand breaks, abasic sites and cross-links, but DSBs are the most toxic [34]. DSB formation leads to rapid induction of foci containing $\gamma \mathrm{H} 2 \mathrm{AX}$, the phosphorylated form of the histone variant $\mathrm{H} 2 \mathrm{AX}$, required for recruitment of many factors that sense and repair DSBs. Thus, $\gamma \mathrm{H} 2 \mathrm{AX}$ is a useful marker of DSB induction and resolution [35-37]. Effects of IGF-1R depletion on $\gamma \mathrm{H} 2 \mathrm{AX}$ were measured initially by Western blotting. Unirradiated DU145 cells showed detectable $\gamma \mathrm{H} 2 \mathrm{AX}$ signal, perhaps due to replication stress [38]. Levels of $\gamma \mathrm{H} 2 \mathrm{AX}$ were enhanced by $5 \mathrm{~Gy}$ ionizing radiation, and control transfectants showed resolution of signal over 24$36 \mathrm{~h}$ (Fig. 2a and b). Following IGF-1R depletion, there was a delay in resolution of $\gamma \mathrm{H} 2 \mathrm{AX}$, which remained detectable for at least $36 \mathrm{~h}$ after irradiation (Fig. 2a and b). It is known that apoptosis can induce $\gamma \mathrm{H} 2 \mathrm{AX}$, typically in an 'apoptotic ring' around the periphery of the nucleus [39]. It is possible that this phenomenon could account, at least in part, for the apparent delay in $\gamma \mathrm{H} 2 \mathrm{AX}$ resolution shown by Western blotting. Therefore, we also used immunofluorescence to monitor irradiation-induced $\gamma \mathrm{H} 2 \mathrm{AX}$ focus formation. Occasional cells were seen with an 'apoptotic ring' or pan- $\gamma \mathrm{H} 2 \mathrm{AX}$ staining (not shown), and these were omitted from quantification of $\gamma \mathrm{H} 2 \mathrm{AX}$ foci. In undamaged cells there were few detectable $\gamma \mathrm{H} 2 \mathrm{AX}$ foci, with a clear increase after irradiation, consistent with results of Western blotting (Fig. 2c). By $24 \mathrm{~h}$, damage-induced $\gamma \mathrm{H} 2 \mathrm{AX}$ foci had resolved in control-transfected cells. Following irradiation of IGF-1R depleted cells, $\gamma \mathrm{H} 2 \mathrm{AX}$ foci were induced in a pattern paralleling that of the controls. However, there was a clear difference at later time points, with a significant excess of $\gamma \mathrm{H} 2 \mathrm{AX}$ foci persisting at $24-36 \mathrm{~h}$ (Fig. 2c and d). This was not due to a large number of foci in a few cells, but rather persistence of foci in the majority of IGF-1R depleted cells: at 24 and $36 \mathrm{~h}$ control transfected DU145 cultures included $14 \%$ and $23 \%$ of cells with foci above background (undamaged) levels, compared with $85 \%$ and $64 \%$ of IGF-1R depleted cells. Therefore, characterization of the $\gamma \mathrm{H} 2 \mathrm{AX}$ response indicated that IGF-1R depletion induced a delay in resolution of irradiation-induced $\gamma \mathrm{H} 2 \mathrm{AX}$.

Although $\gamma \mathrm{H} 2 \mathrm{AX}$ foci form at DSBs, they are not specific for DSBs, and can be induced by other forms of DNA damage [38]. Therefore, we also performed pulsed field gel electrophoresis (PFGE) to quantify DSBs, to investigate whether IGF-1R depletion influenced the time-course of DSB repair. The DNA of DU145 cells was resolved by PFGE into three distinct bands, the upper representing intact chromosomal DNA that was retained in the wells. DSBs generate shorter DNA molecules that are able to migrate through the gel, creating an intermediate broad band/smear of DNA fragments (labelled $*$ in Fig. 3a and c). A lower band, comprising diffuse fragments of relatively low molecular weight (labelled $* *$ in Fig. 3a and c), was seen to increase after 2-6 h, and is likely to represent apoptotic DNA fragmentation. The intensity of the intermediate band, representing DNA that was fragmented by irradiation, was maximal immediately after irradiation, diminished with time, and in control-transfectants had resolved to basal
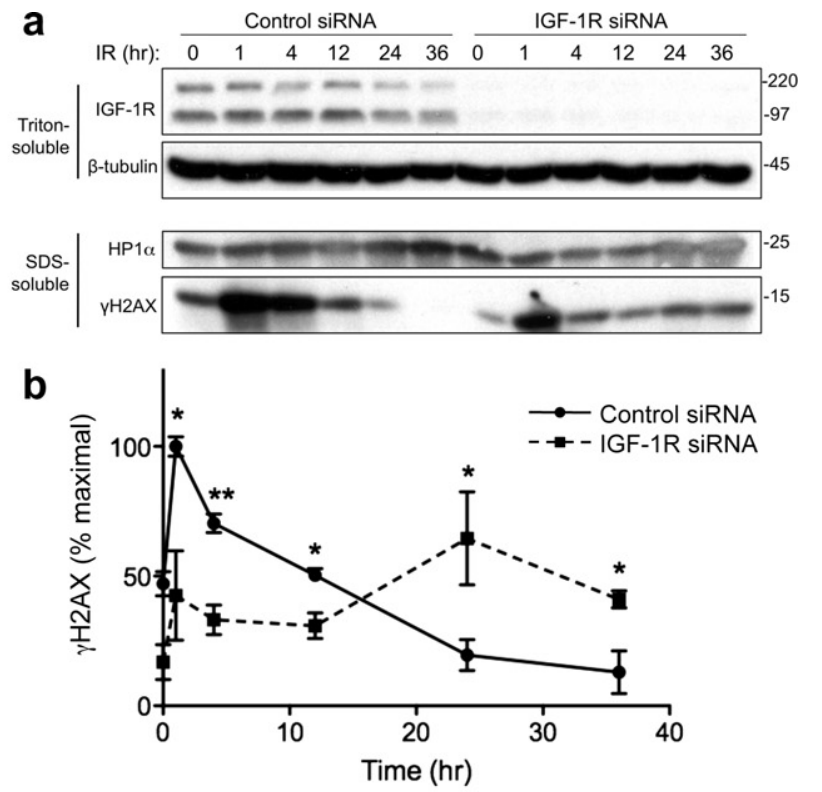

C
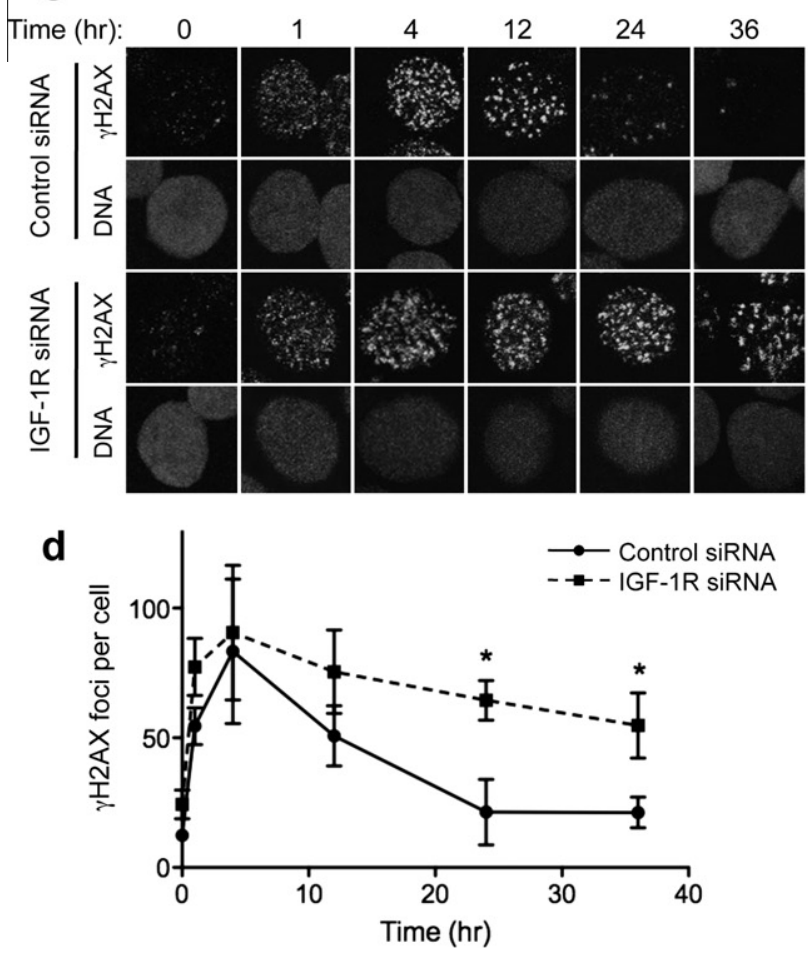

Fig. 2. IGF-1R depletion induces a delay in $\gamma \mathrm{H} 2 \mathrm{AX}$ resolution. (a) DU145 cells were transfected with control or IGF-1R siRNA, and after $48 \mathrm{~h}$ were subjected to $5 \mathrm{~Gy}$ ionizing radiation. After 1-36 h, the cells were fractionated into Triton-soluble and Triton-insoluble, SDS-soluble extracts (see Methods), which were analysed by Western blotting for IGF-1R, $\gamma \mathrm{H} 2 \mathrm{AX}$ and HP1 $\alpha$ as a loading control for the SDSsoluble fraction. (b) Three sets of independently-prepared lysates were analysed as in a), and $\gamma \mathrm{H} 2 \mathrm{AX}$ was quantified, corrected for HP- $1 \alpha$ loading, and expressed as $\%$ maximal $\gamma \mathrm{H} 2 \mathrm{AX}$ signal in control transfectants $1 \mathrm{~h}$ post-irradiation. Control transfectants showed peak $\gamma \mathrm{H} 2 \mathrm{AX}$ induction $1 \mathrm{~h}$ post-irradiation, falling to basal levels at 24-36 h. In IGF-1R depleted cells there was an apparent reduction in $\gamma \mathrm{H} 2 \mathrm{AX}$ signal $1-12 \mathrm{~h}$ post-irradiation, but at $24-36 \mathrm{~h}$ there was significant persistence of $\gamma \mathrm{H} 2 \mathrm{AX}$ compared with controls $\left({ }^{*} p<0.05,{ }^{* *} p<0.01\right.$ by $t$-test). (c) DU145 cells were siRNA-transfected and irradiated (5 Gy) as in (a). At intervals, cells were fixed and stained for $\gamma \mathrm{H} 2 \mathrm{AX}$ and DNA. The cells were examined by confocal microscopy, and representative cells are shown (original magnification $400 \times$ ). (d) Foci were counted for 10-20 nuclei in each condition, and represented graphically as mean focus count per nucleus. After 1-4 h, both cell populations had similar numbers of foci. At 24-36 h, $\gamma \mathrm{H} 2 \mathrm{AX}$ foci had resolved to basal levels in the control cells but persisted following IGF-1R depletion $\left({ }^{*} p<0.05\right.$ by $t$-test). 
a

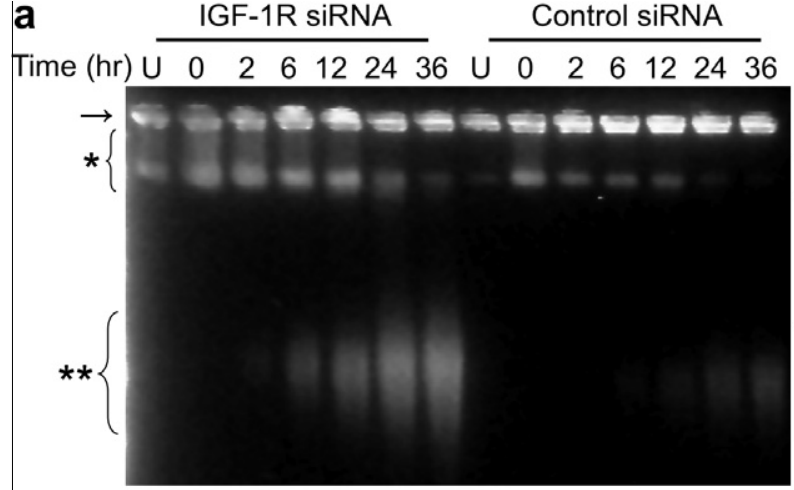

C

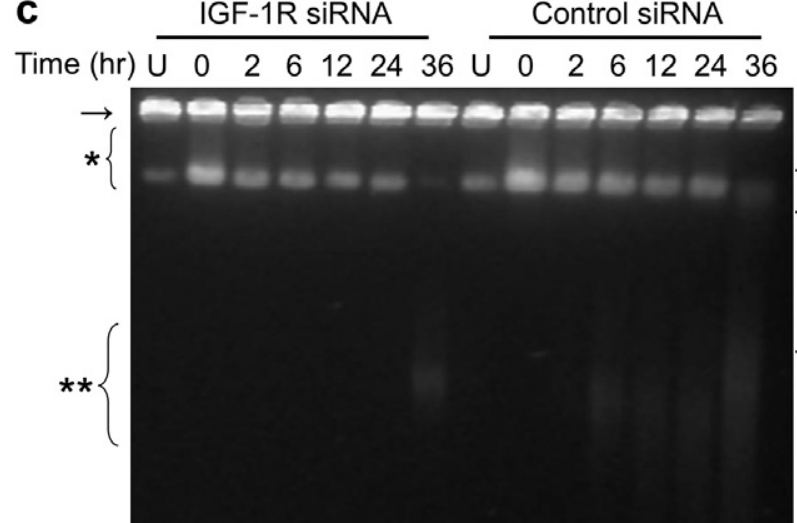

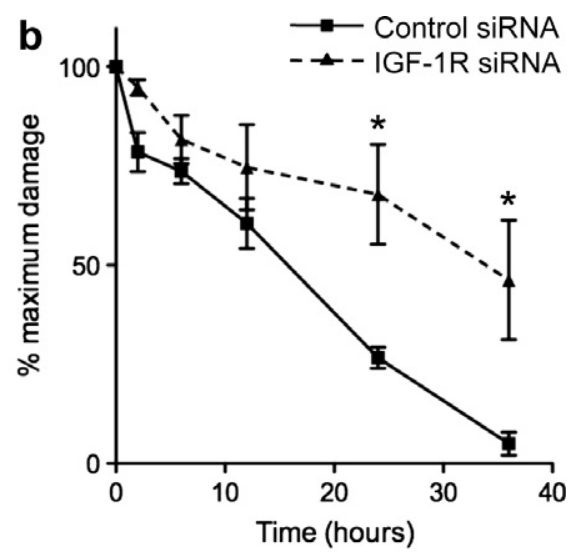

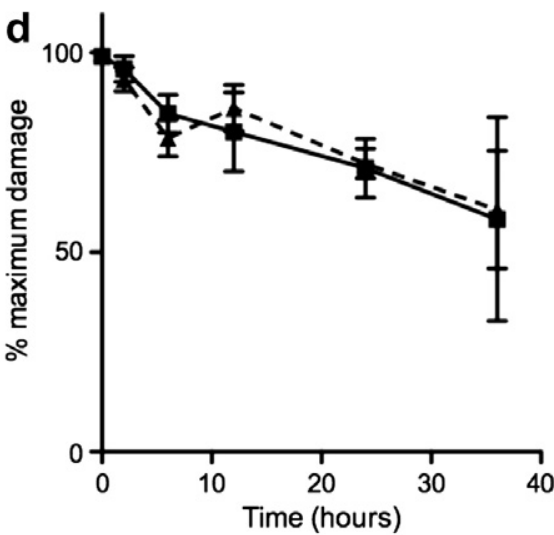

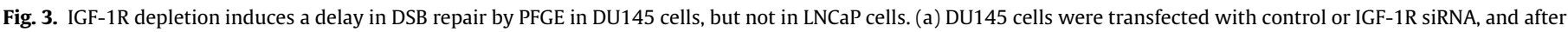

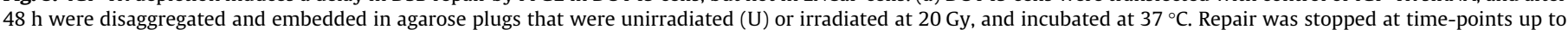

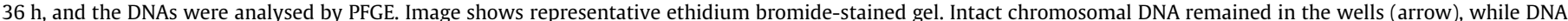

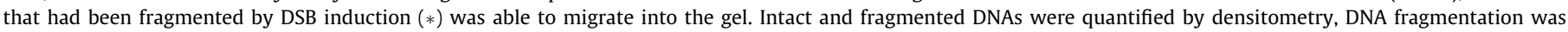

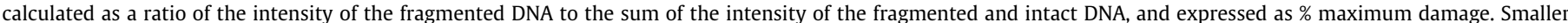

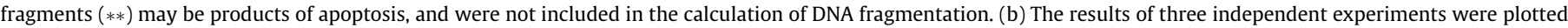

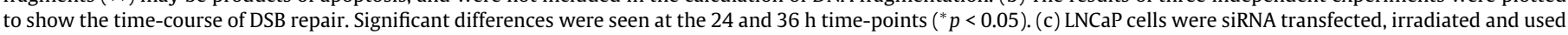

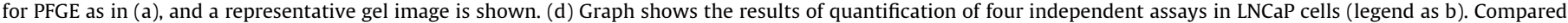
with DU145 cells, control-transfected LNCaP cells showed a slower rate of repair, and there was no difference in repair kinetics upon IGF-1R depletion.

(un-irradiated) levels by $36 \mathrm{~h}$ (Fig. 3a and b). There was a significant difference in the time course of appearance and resolution of fragmented DNA following IGF-1R depletion, with an increase in apoptotic DNA fragmentation, a predictable effect of IGF-1R depletion. Compared with control transfectants, there was also persistence of the intermediate products representing irradiation-induced damage, amounting to 30-40\% excess of unrepaired DSBs at 24-36 h (Fig. 3a and b). The concordance between the PFGE results and $\gamma \mathrm{H} 2 \mathrm{AX}$ quantification by Western blotting and immunofluorescence suggests that the rate of repair of radiation-induced DSB repair was impaired following IGF-1R depletion in DU145 cells.

Compared with DU145 cells, DSB repair in LNCaP was relatively slow and was incomplete at $24 \mathrm{~h}$ (Fig. $3 \mathrm{c}$ and d). The number of unrepaired DSBs generally correlates with the degree of cell killing after irradiation [34,40], and the detection of persisting damage at $24 \mathrm{~h}$ is consistent with the relative radiosensitivity of LNCaP cells (Fig. 1b and c). Similar differences were found in a previous study quantifying DSBs by neutral comet assay: DU145, PC3 and LNCaP cells showed delayed DSB repair compared with normal prostate epithelial cells, with evidence of more damage persisting at $24 \mathrm{~h}$ in LNCaP cells than DU145 [41]. In contrast, a second study using a modified electrophoresis protocol indicated that LNCaP cells repaired a greater fraction of DSBs during the initial fast phase of repair, and DU145 had more unrepaired DSBs at $24 \mathrm{~h}$, although as here, LNCaP cells were found to be more radiosensitive than DU145 cells [32].
In contrast to findings in DU145 cells, LNCaP cells showed no change in the time course of DSB repair following IGF-1R depletion (Fig. $3 \mathrm{c}$ and d). Repair of DSBs is accomplished in mammalian cells by HR or non-homologous end joining (NHEJ). HR occurs via single strand annealing, when a DSB arises between two repeated sequences in the same orientation, or gene conversion, which uses an identical template, usually a sister chromatid, and results in high fidelity repair $[42,43]$. In considering why human prostate cancer cell lines respond differently to IGF-1R depletion, we note that LNCaP and PC3 cells lack functional PTEN, while DU145 expresses wild-type PTEN. A recent report suggested that IGF-1R inhibition radiosensitizes only PTEN wild-type cells, without effect in PTEN-null PC3 cells [44]. However, we have observed consistent radiosensitization of PC3 cells by IGF-1R depletion, both in the current study and previously [23]. In contrast, in IGF-1R depleted LNCaP cells we saw only modest radiosensitization (Fig. 1b and c) and no change in the time-course of DSB resolution (Fig. 3c and d). LNCaP cells are deficient in the adaptor protein IRS-1, which links the IGF-1R to the PI3K-AKT pathway [27]; see Fig. 1a). IRS-1 is reported to form IGF-regulated complexes with RAD51, the recombinase required for the strand invasion step of HR, thereby influencing RAD51 subcellular localization and function [18]. We speculated that the lack of IRS-1 could contribute to the relatively slow repair rate in LNCaP, noted also by [41], and to the inability to influence repair by IGF-1R depletion. 
Therefore, to investigate directly whether IGF-1R depletion can influence DSB repair by HR, we used a recombination reporter that encodes inactive green fluorescent protein (GFP). When cleaved by the endonuclease I-Sce I, functional GFP can be restored by gene conversion using a donor fragment of GFP cDNA present on the same plasmid [31]. DU145 pDR-GFP stable transfectants were transiently transfected with control or IGF-1R siRNAs, and with pCMVI-Sce and the transfection marker pDSRed2-Mito. Fluorescent cells were imaged by fluorescence microscopy (Fig. 4a) and quantified by flow cytometry (Fig. 4 b). In control siRNA transfectants, $\sim 7-$ $8 \%$ of cells were GFP positive, indicating that they were competent to perform HR (Fig. $4 \mathrm{~b}$ and c). These figures are consistent with 3$10 \%$ GFP positivity using this assay in other cell types [31,45]. Compared with controls, IGF-1R depletion resulted in $\sim 30 \%$ decrease in the percent of GFP-positive cells, representing a significant reduction in the ability to accomplish HR ( $p<0.005$; Fig. $4 \mathrm{~b}$ and $c)$. This effect is consistent with the ability of IGF-I to promote HR in murine fibroblasts and murine and human mesangial cells [18,45], and is likely to contribute to the radiosensitization (Fig. 1b and c) and delay in DNA repair (Figs. 2 and 3) induced by IGF-1R depletion. The observed reduction in HR upon IGF-1R depletion could be compatible with the reported requirement for a functional IGF$1 \mathrm{R}$ to tyrosine phosphorylate IRS-1, disrupting interaction with RAD51 and allowing proper RAD51 function [18]. However, IRS-1 is predominantly cytoplasmic in DU145 cells (not shown), and we could not detect an interaction between IRS-1 and RAD51 (Fig. 4d). Consequently, we sought an alternative explanation for the HR defect induced by IGF-1R depletion in DU145 cells.

IGFs have well-recognized effects on cell cycle distribution, which is known to influence radiosensitivity and choice of repair pathway $[34,40,46,47]$. Therefore, we assessed effects of IGF-1R depletion on cell cycle distribution following $5 \mathrm{~Gy}$ ionizing radiation. Quantification of the sub-G1 population indicated that fewer than $10 \%$ of DU145 and LNCaP cells underwent apoptosis during the first $12 \mathrm{~h}$ post-irradiation, with a (non-significant) increase at $24 \mathrm{~h}$ following IGF-1R-depletion of DU145 but not LNCaP cells. These results paralleled the yield of relatively small DNA fragments, presumed due to apoptosis, on PFGE (marked $* *$ on Figs. 3a and c). Apoptosis induction is highly likely to contribute to the ability of IGF-1R depletion to enhance radiosensitivity (Fig. 1). Viable DU145 cells showed a progressive reduction in the G1 population, with increasing G2-M arrest (from 26\% to $40 \%$ of cells) in control transfectants $2-12 \mathrm{~h}$ after irradiation, and reverting to a profile similar to undamaged cells by $24 \mathrm{~h}$ (Table 2 , upper). Following IGF-1R-depletion, there was more modest reduction in G1 and accumulation in G2-M after irradiation (G2-M population increased by $\sim 7 \%$ at $4-6 \mathrm{~h}$ ). A very similar pattern was observed in the LNCaP cell line, where post-irradiation G2-M arrest was attenuated by IGF-1R depletion (Table 2, lower). In considering the potential consequences of these effects, we note that mammalian cells are relatively radioresistant in $S$ phase, with greatest radiosensitivity in early G1 [34]. An increase in the G1 population could, therefore, contribute to the ability of IGF-1R depletion to enhance radiosensitivity. However, given that IGF-1R depletion induced similar effects on cell cycle distribution in DU145 and LNCaP cells, it is unlikely that cell cycle effects per se could account for the differences in radiosensitivity and DSB repair induced by IGF-1R depletion in these two cell lines. In addition to influencing intrinsic radioresistance, cell cycle phase plays an important role in choice of DSB repair pathway, with access to a homologous template for repair by HR only during late S and G2 phases. Although the GFP reporter we used to quantify HR provides a repair template that is accessible independent of cell cycle phase, the loading of RAD51 filaments onto DNA is cell cycle dependent, requiring CDK-mediated phosphorylation of BRCA2 [48]. Therefore, it is a
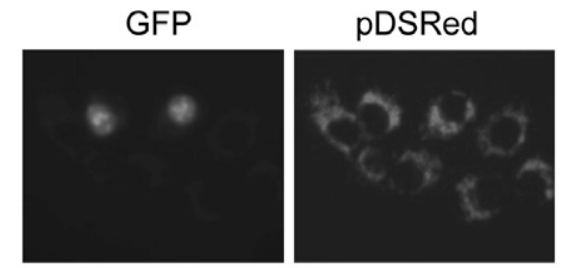

b
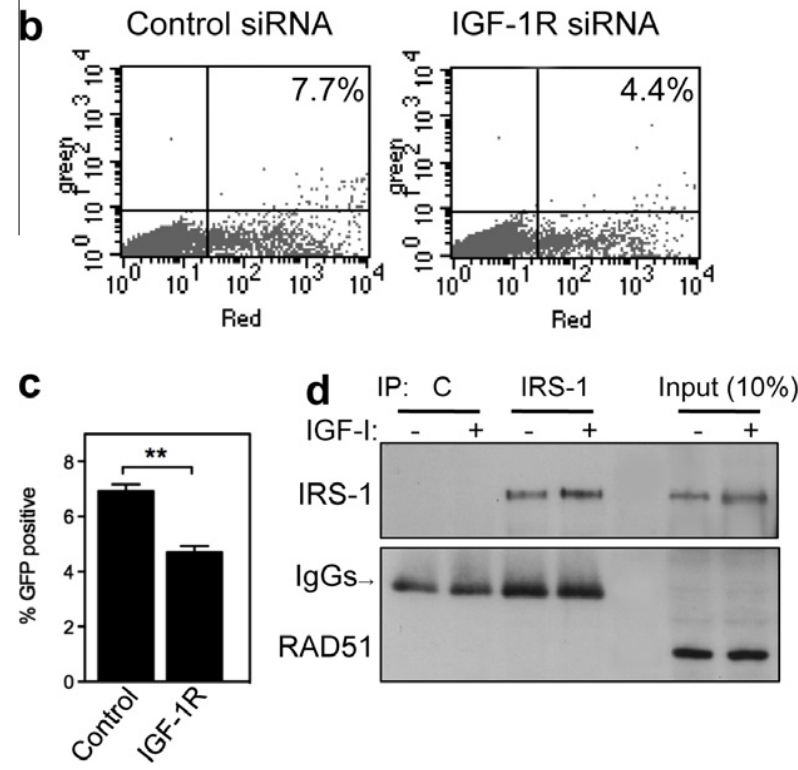

Fig. 4. IGF-1R depletion impairs the ability of DU145 prostate cancer cells to repair DSBs by homologous recombination. DU145 cells were stably transfected with pDRGFP, and plasmid integration was confirmed by PCR in five puromycin-resistant clones (not shown). Stable transfectants were transiently transfected with control or IGF-1R siRNAs and $24 \mathrm{~h}$ later were transfected with pCMV-I-Sce I and pDSRed2Mito as a transfection marker. After a further $48 \mathrm{~h}$ (i.e. $72 \mathrm{~h}$ post-siRNA transfection) cells were analysed by (a) light microscopy, showing a cluster of eight transfected (pDS-Red2-Mito positive) cells, of which two were GFP positive; (b) flow cytometry, showing representative results from one pDR-GFP clone. Homologous recombination efficiency was expressed as \% red and green cells (i.e. upper right quadrant) as a percentage of the total transfected cells (i.e. upper right plus lower right quadrants). Cells in the lower left quadrant were untransfected, and there were occasional cells in the upper left quadrant (GFP positive, pDS-RedMito negative) that were omitted from the analysis. (c) Bar graph shows mean \% GFP positivity from two independent assays of five DU145 pDR-GFP clones; bars, SEM. There was a significant reduction in repair by HR following IGF-1R depletion $\left({ }^{* *} p<0.005\right.$ by paired $t$ test). (d) DU145 cells were serum-starved overnight and treated with solvent or $50 \mathrm{nM}$ IGF-I for $3 \mathrm{~h}$, shown previously to attenuate the IRS-1:RAD51 interaction detected in serum starved IGF-1R-transfected murine fibroblasts [18]. Whole cell extracts were immunoprecipitated with control IgG (C) or IRS-1 antibody and blotted for IRS-1 and RAD51. RAD51 was detected in whole cell extract but not in IRS-1 immunoprecipitates.

possible that the attenuated G2-M accumulation of IGF-1R depleted DU145 cells (Table 2) may contribute to the reduction in HR.

In conclusion, these results demonstrate a role for the IGF1R in the cellular response to DNA damage in DU145 prostate cancer cells, at least in part through effects on HR. However, the apparent $30-40 \%$ defect in DSB repair in DU145 cells (Fig. 3a and b) is in excess of the modest defect reported using PFGE to quantify repair of ionizing radiation-induced DSBs in cells defective in HR [46], and points to the possibility that NHEJ may also be defective. Finally, our findings suggest that there may be merit in combining IGF$1 \mathrm{R}$ inhibitory drugs with radiation therapy for primary prostate cancer, and potentially also with DNA damaging cytotoxic drugs as treatment for metastatic disease. Effective clinical application of this approach will require careful consideration of the scheduling of the IGF-1R therapeutic with damage [49], and of consequences for toxicity to IGF-1R-expressing normal tissues. 
Table 2

Effect of IGF-1R depletion on cell cycle distribution after irradiation.

\begin{tabular}{|c|c|c|c|c|c|c|c|c|}
\hline $\mathrm{Hr}$ & Sub-G1 & G1 & $\mathrm{S}$ & G2-M & Sub-G1 & G1 & $\mathrm{S}$ & G2-M \\
\hline \multicolumn{5}{|c|}{ DU145 control } & \multicolumn{4}{|c|}{ DU145 IGF-1R depleted } \\
\hline 0 & $2.1 \pm 0.5$ & $58.2 \pm 5.3$ & $13.6 \pm 1.2$ & $26.0 \pm 3.6$ & $4.0 \pm 0.1$ & $62.1 \pm 5.9$ & $13.5 \pm 1.5$ & $18.8 \pm 6.0$ \\
\hline 1 & $1.8 \pm 0.3$ & $54.6 \pm 3.0$ & $17.0 \pm 2.2$ & $26.5 \pm 0.5$ & $5.1 \pm 2.6$ & $58.4 \pm 3.1$ & $14.2 \pm 3.1$ & $20.8 \pm 4.0$ \\
\hline 2 & $2.1 \pm 0.5$ & $51.5 \pm 7.6$ & $17.2 \pm 3.1$ & $29.2 \pm 3.9$ & $4.1 \pm 1.7$ & $56.7 \pm 0.9$ & $14.4 \pm 2.6$ & $23.5 \pm 1.2$ \\
\hline 4 & $2.9 \pm 0.1$ & $42.4 \pm 2.4$ & $17.2 \pm 1.6$ & $37.4 \pm 0.7$ & $4.0 \pm 0.8$ & $53.8 \pm 4.5$ & $14.8 \pm 2.1$ & $25.8 \pm 3.0$ \\
\hline 6 & $2.3 \pm 0.4$ & $39.9 \pm 5.0$ & $18.3 \pm 3.5$ & $39.4 \pm 1.1$ & $4.0 \pm 0.6$ & $52.6 \pm 6.6$ & $15.2 \pm 0.9$ & $25.2 \pm 6.9$ \\
\hline 12 & $3.2 \pm 0.5$ & $34.0 \pm 6.0$ & $22.9 \pm 6.1$ & $39.9 \pm 0.4$ & $3.4 \pm 0.6$ & $53.3 \pm 9.9$ & $16.1 \pm 0.7$ & $21.3 \pm 7.9$ \\
\hline 24 & $6.0 \pm 1.1$ & $53.9 \pm 5.6$ & $16.3 \pm 2.2$ & $23.8 \pm 1.6$ & $11.3 \pm 3.0$ & $57.3 \pm 0.7$ & $12.7 \pm 1.9$ & $17.3 \pm 3.0$ \\
\hline \multicolumn{5}{|c|}{ LNCaP control } & \multicolumn{4}{|c|}{ LNCaP IGF-1R depleted } \\
\hline 0 & $4.0 \pm 3.4$ & $47.8 \pm 3.0$ & $15.0 \pm 0.7$ & $27.1 \pm 0.5$ & $4.7 \pm 4.0$ & $61.1 \pm 2.0$ & $12.1 \pm 0.6$ & $20.3 \pm 1.4$ \\
\hline 1 & $4.0 \pm 3.5$ & $45.0 \pm 3.3$ & $22.1 \pm 1.2$ & $23.6 \pm 0.1$ & $7.4 \pm 5.7$ & $69.2 \pm 4.4$ & $10.4 \pm 0.8$ & $12.9 \pm 0.6$ \\
\hline 2 & $3.5 \pm 2.9$ & $41.2 \pm 1.9$ & $12.5 \pm 0.5$ & $30.1 \pm 0.5$ & $7.6 \pm 6.6$ & $61.1 \pm 4.1$ & $8.8 \pm 0.7$ & $21.0 \pm 1.9$ \\
\hline 4 & $3.1 \pm 2.6$ & $36.7 \pm 2.3$ & $12.9 \pm 0.5$ & $37.1 \pm 0.6$ & $2.8 \pm 1.7$ & $58.4 \pm 0.6$ & $15.0 \pm 0.3$ & $23.5 \pm 0.7$ \\
\hline 6 & $4.6 \pm 3.2$ & $33.2 \pm 2.0$ & $13.2 \pm 0.6$ & $37.8 \pm 1.0$ & $1.7 \pm 1.2$ & $58.1 \pm 0.4$ & $13.3 \pm 0.2$ & $26.3 \pm 0.5$ \\
\hline 12 & $3.7 \pm 2.3$ & $36.2 \pm 2.7$ & $11.8 \pm 0.35$ & $40.7 \pm 0.3$ & $5.6 \pm 3.8$ & $60.1 \pm 2.2$ & $12.0 \pm 0.5$ & $19.8 \pm 0.9$ \\
\hline 24 & $8.0 \pm 6.0$ & $52.1 \pm 5.2$ & $14.2 \pm 0.4$ & $22.4 \pm 0.3$ & $8.1 \pm 5.7$ & $63.4 \pm 4.0$ & $8.3 \pm 0.5$ & $17.5 \pm 1.1$ \\
\hline
\end{tabular}

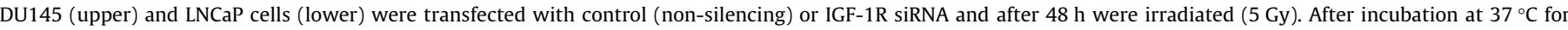

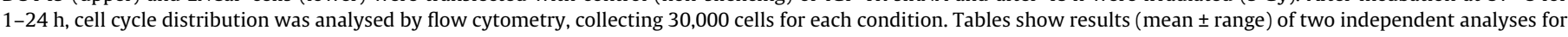
each cell line.

\section{Conflict of interest statement}

The authors have no conflict of interest to declare.

\section{Acknowledgements}

This work was supported by the NIHR Oxford Biomedical Research Centre, Molecular and Cellular Medicine Board of the MRC, Prostate Action, British Urological Foundation, HEFCE Clinical Senior Lectureship to V.M.M., Cancer Research UK Clinical Training Fellowship to M.M.C., and Professor Tom Stapleton Endowment funding to Y.W. We are grateful to Professor Ian Hickson for plasmids pDR-GFP and pCMV-Sce, and to Drs. Peter McHugh and Eric O'Neill for comments on the manuscript.

\section{References}

[1] Pollak M. Insulin and insulin-like growth factor signalling in neoplasia. Nat Rev Cancer 2008;8:915-28.

[2] Chitnis MM, Yuen JS, Protheroe AS, Pollak M, Macaulay VM. The type 1 insulinlike growth factor receptor pathway. Clin Cancer Res 2008;14:6364-70.

[3] Hellawell GO, Turner GD, Davies DR, Poulsom R, Brewster SF, Macaulay VM. Expression of the type 1 insulin-like growth factor receptor is up-regulated in primary prostate cancer and commonly persists in metastatic disease. Cancer Res 2002;62:2942-50.

[4] Grzmil M, Hemmerlein B, Thelen P, Schweyer S, Burfeind P. Blockade of the type I IGF receptor expression in human prostate cancer cells inhibits proliferation and invasion, up-regulates IGF binding protein-3, and suppresses MMP-2 expression. J Pathol 2004;202:50-9.

[5] Krueckl SL, Sikes RA, Edlund NM, et al. Increased insulin-like growth factor I receptor expression and signaling are components of androgen-independent progression in a lineage-derived prostate cancer progression model. Cancer Res 2004;64:8620-9.

[6] Liao Y, Abel U, Grobholz R, et al. Up-regulation of insulin-like growth factor axis components in human primary prostate cancer correlates with tumor grade. Hum Pathol 2005;36:1186-96.

[7] Ryan CJ, Haqq CM, Simko J, et al. Expression of insulin-like growth factor-1 receptor in local and metastatic prostate cancer. Urol Oncol 2007;25:134-40.

[8] Turney BW, Turner GD, Brewster SF, Macaulay VM. Serial analysis of resected prostate cancer suggests up-regulation of type 1 IGF receptor with disease progression. BJU Int 2011;107:1488-99.

[9] Nickerson T, Chang F, Lorimer D, Smeekens SP, Sawyers CL, Pollak M. In vivo progression of LAPC-9 and LNCaP prostate cancer models to androgen independence is associated with increased expression of insulin-like growth factor I (IGF-I) and IGF-I receptor (IGF-IR). Cancer Res 2001;61:6276-80.

[10] Pandini G, Genua M, Frasca F, Vigneri R, Belfiore A. Sex steroids upregulate the IGF-1R in prostate cancer cells through a nongenotropic pathway. Ann NY Acad Sci 2009;1155:263-7.

[11] Dunn SE, Hardman RA, Kari FW, Barrett JC. Insulin-like growth factor 1 (IGF-1) alters drug sensitivity of HBL100 human breast cancer cells by inhibition of apoptosis induced by diverse anticancer drugs. Cancer Res 1997;57:2687-93.
[12] Iwasa T, Okamoto I, Suzuki M, et al. Inhibition of insulin-like growth factor 1 receptor by CP-751,871 radiosensitizes non-small cell lung cancer cells. Clin Cancer Res 2009;15:5117-25.

[13] Flanigan SA, Pitts TM, Eckhardt SG, et al. The insulin-like growth factor I receptor/insulin receptor tyrosine kinase inhibitor PQIP exhibits enhanced antitumor effects in combination with chemotherapy against colorectal cancer models. Clin Cancer Res 2010;16:5436-46.

[14] Riesterer O, Yang Q, Raju U, et al. Combination of anti-IGF-1R antibody A12 and ionizing radiation in upper respiratory tract cancers. Int J Radiat Oncol Biol Phys 2011;79:1179-87.

[15] Basu B, Olmos D, de Bono JS. Targeting IGF-1R: throwing out the baby with the bathwater? Br J Cancer 2011;104:1-3.

[16] Turner BC, Haffty BG, Narayanan L, et al. Insulin-like growth factor-I receptor overexpression mediates cellular radioresistance and local breast cancer recurrence after lumpectomy and radiation. Cancer Res 1997;57:3079-83.

[17] Macaulay VM, Salisbury AJ, Bohula EA, Playford MP, Smorodinsky NI, Shiloh Y. Downregulation of the type 1 insulin-like growth factor receptor in mouse melanoma cells is associated with enhanced radiosensitivity and impaired activation of Atm kinase. Oncogene 2001;20:4029-40.

[18] Trojanek J, Ho T, Del Valle L, et al. Role of the insulin-like growth factor I/ insulin receptor substrate 1 axis in Rad51 trafficking and DNA repair by homologous recombination. Mol Cell Biol 2003;23:7510-24.

[19] Zeng X, Sachdev D, Zhang H, Gaillard-Kelly M, Yee D. Sequencing of type I insulin-like growth factor receptor inhibition affects chemotherapy response in vitro and in vivo. Clin Cancer Res 2009;15:2840-9.

[20] Pandini G, Wurch T, Akla B, Corvaia N, Belfiore A, Goetsch L. Functional responses and in vivo anti-tumour activity of h7C10: a humanised monoclonal antibody with neutralising activity against the insulin-like growth factor-1 (IGF-1) receptor and insulin/IGF-1 hybrid receptors. Eur J Cancer 2007;43:1318-27.

[21] Yuen JS, Macaulay VM. Targeting the type 1 insulin-like growth factor receptor as a treatment for cancer. Expert Opin Ther Targets 2008;12:589-603.

[22] Buck E, Mulvihill M. Small molecule inhibitors of the IGF-1R/IR axis for the treatment of cancer. Expert Opin Investig Drugs 2011;20:605-21.

[23] Rochester MA, Riedemann J, Hellawell GO, Brewster SF, Macaulay VM. Silencing of the IGF1R gene enhances sensitivity to DNA-damaging agents in both PTEN wild-type and mutant human prostate cancer. Cancer Gene Ther 2005; $12: 90-100$.

[24] Stone KR, Mickey DD, Wunderli H, Mickey GH, Paulson DF. Isolation of a human prostate carcinoma cell line (DU 145). Int J Cancer 1978;21:274-81.

[25] Kaighn ME, Narayan KS, Ohnuki Y, Lechner JF, Jones LW. Establishment and characterization of a human prostatic carcinoma cell line (PC-3). Invest Urol 1979;17:16-23.

[26] Horoszewicz JS, Leong SS, Kawinski E, et al. LNCaP model of human prostatic carcinoma. Cancer Res 1983;43:1809-18.

[27] Reiss K, Wang JY, Romano G, et al. IGF-I receptor signaling in a prostatic cancer cell line with a PTEN mutation. Oncogene 2000;19:2687-94.

[28] Bohula EA, Salisbury AJ, Sohail M, et al. The efficacy of small interfering RNAs targeted to the type 1 insulin-like growth factor receptor (IGF1R) is influenced by secondary structure in the IGF1R transcript. J Biol Chem 2003;278:15991-7.

[29] Pinto M, Prise KM, Michael BD. Quantification of radiation induced DNA double-strand breaks in human fibroblasts by PFGE: testing the applicability of random breakage models. Int J Radiat Biol 2002;78:375-88.

[30] Lundin C, North M, Erixon K, et al. Methyl methanesulfonate (MMS) produces heat-labile DNA damage but no detectable in vivo DNA double-strand breaks. Nucleic Acids Res 2005;33:3799-811. 
[31] Pierce AJ, Johnson RD, Thompson LH, Jasin M. XRCC3 promotes homologydirected repair of DNA damage in mammalian cells. Genes Dev 1999;13:2633-8.

[32] El-Awady RA, Dikomey E, Dahm-Daphi J. Radiosensitivity of human tumour cells is correlated with the induction but not with the repair of DNA doublestrand breaks. Br J Cancer 2003;89:593-601.

[33] Aleksic T, Chitnis MM, Perestenko OV, et al. Type 1 insulin-like growth factor receptor translocates to the nucleus of human tumor cells. Cancer Res 2010;70:6412-9.

[34] Hinz JM, Yamada NA, Salazar EP, Tebbs RS, Thompson LH. Influence of doublestrand-break repair pathways on radiosensitivity throughout the cell cycle in CHO cells. DNA Repair (Amst) 2005;4:782-92.

[35] Chowdhury D, Keogh MC, Ishii H, Peterson CL, Buratowski S, Lieberman J. Gamma-H2AX dephosphorylation by protein phosphatase 2A facilitates DNA double-strand break repair. Mol Cell 2005;20:801-9.

[36] Stucki M, Jackson SP. GammaH2AX and MDC1: anchoring the DNA-damageresponse machinery to broken chromosomes. DNA Repair (Amst) 2006;5:534-43.

[37] Polo SE, Jackson SP. Dynamics of DNA damage response proteins at DNA breaks: a focus on protein modifications. Genes Dev 2011;25:409-33.

[38] Ward IM, Chen J. Histone H2AX is phosphorylated in an ATR-dependent manner in response to replicational stress. J Biol Chem 2001;276:47759-62.

[39] Solier S, Pommier Y. The apoptotic ring: a novel entity with phosphorylated histones H2AX and H2B and activated DNA damage response kinases. Cell Cycle 2009;8:1853-9.

[40] Radford IR. The level of induced DNA double-strand breakage correlates with cell killing after X-irradiation. Int J Radiat Biol Relat Stud Phys Chem Med 1985;48:45-54.
[41] Fan R, Kumaravel TS, Jalali F, Marrano P, Squire JA, Bristow RG. Defective DNA strand break repair after DNA damage in prostate cancer cells: implications for genetic instability and prostate cancer progression. Cancer Res 2004;64:8526-33.

[42] West SC, Chappell C, Hanakahi LA, Masson JY, McIlwraith MJ, Van Dyck E. Double-strand break repair in human cells. Cold Spring Harb Symp Quant Biol 2000;65:315-21.

[43] Jackson SP. Sensing and repairing DNA double-strand breaks. Carcinogenesis 2002;23:687-96.

[44] Isebaert SF, Swinnen JV, McBride WH, Haustermans KM. Insulin-like growth factor-type 1 receptor inhibitor NVP-AEW541 enhances radiosensitivity of PTEN wild-type but not PTEN-deficient human prostate cancer cells. Int J Radiat Oncol Biol Phys 2011;81:239-47.

[45] Yang S, Chintapalli J, Sodagum L, et al. Activated IGF-1R inhibits hyperglycemia-induced DNA damage and promotes DNA repair by homologous recombination. Am J Physiol Renal Physiol 2005;289:F1144-52.

[46] Rothkamm K, Kruger I, Thompson LH, Lobrich M. Pathways of DNA doublestrand break repair during the mammalian cell cycle. Mol Cell Biol 2003;23:5706-15.

[47] Shrivastav M, De Haro LP, Nickoloff JA. Regulation of DNA double-strand break repair pathway choice. Cell Res 2008;18:134-47.

[48] Esashi F, Christ N, Gannon J, et al. CDK-dependent phosphorylation of BRCA2 as a regulatory mechanism for recombinational repair. Nature 2005;434:598-604.

[49] Zeng X, Zhang H, Oh A, Zhang Y, Yee D. Enhancement of doxorubicin cytotoxicity of human cancer cells by tyrosine kinase inhibition of insulin receptor and type I IGF receptor. Breast Cancer Res Treat 2011. 